\title{
MULTIPLE TERRITORIAL IDENTITIES AND MULTILEVEL POLITIES
}

\author{
Luis Moreno
}

\section{Introduction}

Theories related to the territorial dimension of power have often been limited to the discussion of the spatial efficiency or inefficiency of state institutions in the provision of public services. Such partial treatment has minimized the comprehensive study of: (a) The development of modern states (state formation, nation-building, mass democratization); (b) Multiple territorial identities and the legitimation of political institutions; (c) Intergovernmental relations within multilevel polities; and (d) The processes of governance rescaling in the global context.

Modernization brought about the idea of all-embracing state national identities rooted in both cultural and civic axes. The social theory of functionalism, in particular, has insisted on its interpretation that internal territorial differences within nation states had to disappear as a pre-requisite for the extension of liberal democracy and franchised politics. As communication of political, economic and cultural matters increased, the peoples of different territories would develop a new common identity, which would transcend their differences (Deutsch, 1966). The centre-periphery dichotomy was destined to decline in importance as society became 'modernized' by means of eliteinitiated policies aimed at achieving social standardization (for example, common language and citizenship entitlements). Likewise, cultural identities of ethnic groups and minorities would be replaced by a set of class-orientated conflicts, or conflicts among interest groups. History has falsified such analyses. ${ }^{1}$

\footnotetext{
${ }^{1}$ For William Safran, one of the prominent characteristics of American social science in general, and the behaviouralist-functionalist school of political science in particular, is its ahistoricist bias. History is rejected on two grounds: "First [...] as a succession of events that [...] do not lend themselves to comparison and generalization...Second [...] because it is associated with pre-modern (primitive) societies..." (1987: 13). 'Mainstream' Marxists have also taken a functionalist approach to the analysis of political integration and modernization (Connor, 1984).
} 
Identity can be regarded as the result of a process of synthesis by which the individual seeks to integrate various interactive elements. The discontinuity and dislocation of social arrangements allow different identities to relate to each other in quite a contingent manner. Unitary identities have become increasingly questioned. While being corroded by the forces of globalization, they have also been subject to fragmentation, competition and overlapping elements of a multiple and diverse nature. In plural societies individuals are frequently tied to cultural reference groups which might be in competition among themselves. This concurrence results in a multiplicity of dynamic and often shared socio-political identities, which are not necessarily and explicitly expressed. Therefore, identity markers are malleable, and the intensity of their manifestation greatly depends upon circumstantial factors.

In fact, identities are shared in various degrees by individuals, and are subject to constant internalisation by group members in different ways. Supra-national levels of ascription (for example, European) can integrate state and sub-state identities in apparent conflict among themselves. The fact that two identities can be referred to a larger entity does not preclude the possible incompatibility of their relationship. That would be the case in deeply divided societies where self-identification by citizens is belligerent (for example, Republicans and Loyalists in Northern Ireland). Arguably, the subsuming of those competing identities within a larger institutional context (EU) implies somehow a nexus of congruence between both forms of selfidentification.

This chapter deals with multiple territorial identities and multilevel polities. As a general conceptual premise, multilevel citizenship is considered as a compound of collective attachments and a product of nested identities formed at the various contextual levels of citizens' political attachments (supra-state, state, sub-state). It legitimizes political life in contemporary societies (Berg, 2007; Hepburn, 2011).

Following the analytical sequence spelt out above, the next section examines the processes associated with political modernity as a background for subsequent discussions on multiple identities and the legitimation of political institutions, the interdependence within multilevel polities, and the re-scaling of governance in the global context. The European context serves as a primary context of analysis for ideas and concepts under examination.

\section{Modern state formation, nation-building and mass democratization}


Traditionally, the cornerstone of state formation and nation-building - principally in the European tradition-- has been the creation of a common national identity throughout a specified territory under one central authority, or through the union of existing territorial units into a nation-state. However, this idea of 'one state, one people,' which was transported worldwide as a result of European colonialism, is a long way from having been accomplished in a variety of countries around the world. Most nation-states have had long-standing traditions of internal diversity and strong ethno-territorial collective identities. All-embracing and exclusive nation-state identities have been problematic in many cases (Moreno, 2005).

Far from being coherent and uniform, societies not only exhibit diversity but also develop mutually interdependent and interacting structures and cleavages. In modern times, the development of industrialization, urbanization, and social communication has characterized to different degrees the processes of state formation, nation-building, and mass democratization. Modernization has exposed multiple identities, which may be eventually politicized and require accommodation or conflict management. The new millennium has witnessed the salience of the politics of identity and differentiation across the world (Moreno and Colino, 2010).

According to classical conceptualization by Max Weber, the state embodies the legal order of a given territory and exercises the monopoly of the legitimate use of force. ${ }^{2}$ Inheritor of the ancient Greek concept of politeia (polity), or politic body, the state in Europe was built in various degrees and dynamics since around the twelfth century until the end of the eighteenth century. More concretely, the period 1485-1789 saw the building of most modern European nationstates. ${ }^{3}$ According to Stein Rokkan, the second phase of nationbuilding, the subsequent processes of mass democratization and the construction of the welfare states completed the main four-phase process of political development in Europe. The exercise of civil and political rights 'spilt over' into social citizenship at all supranational, national, regional and local levels. In Europe, the consolidation of

\footnotetext{
2 In a more general sense, a political system (politischer Verband) is an organization that is structured in a hierarchical manner aiming at maintaining civic order in a defined territorial context (Weber, 1947).

${ }^{3}$ Arguably, Spain was the first modern state in Europe when the Catholics Kings took control dynastically of the two main territories in the Iberian Peninsula (Moreno, 2001).
} 
Marshall's third cycle of social citizenship ${ }^{4}$ was meant to be achieved in the fourth phase of its system building (Flora et al, 1999). ${ }^{5}$

As a result of these historical developments, two broad models of state configuration can be identified: unitary and plural. This unitaryplural typology finds expression in two corresponding systems of government: centralized, where unitary decision-making is concentrated in one core, and decentralized, with a dispersion of power throughout distinct layers of government, including devolved, federal and confederal systems. However, these classical types have evolved and adapted themselves to changing scenarios that have somewhat blurred their original 'yardsticks' or defining traits. The following review of some cases serves to illustrate such variations.

Although nominally confederal, Switzerland can be considered as a federal republic since the inception of the 1848 Constitution after the Sonderbundeskrieg and the factual disappearance of the myth of the canton sovereignty. France has steadily been cited as the foremost example of a unitary and centralized system. Nonetheless, deconcentration has given way to the establishment of directly elected regional councils. Both Belgium and Canada were originally unitary countries that have transformed into formal federations within which some of their constituent parts have considered the possibility of secession. In Italy, the initial process of state formation and nationbuilding under the Savoy dynasty adopted a highly unitary and centralized form after the Risorgimento (1870). During the initial phase of Italy's state formation, the promotion of the new national identity was strong and aimed at placing itself above the many substate identities which had survived for centuries. The Fascist regime (1922-1943) enforced national homogeneity, but in 1948, the democratic constitution recognized the regions as political bodies with 'devolved' administrative and legislative powers.

A considerable number of democracies in the Western hemisphere are composed along multinational, multicultural and multilingual lines

\footnotetext{
${ }^{4}$ This was viewed as the subsequent historical stage once political and civil citizenship had been realized (Marshall 1950). Marshall's argument for social citizenship can be regarded as a dynamic account --rather than as an evolutionary theory-- of the struggle between the extension of political equality and social rights, on the one hand, and the capitalist market and social class, on the other hand.

${ }^{5}$ Rokkan drew attention on the interrelations between internal structuring and external boundary-building for understanding the connections between state formation (military and administrative), nation-building (cultural), and the development of mass democracies (political). Welfare development is to be regarded as the latter stage in Rokkan's attempt to put forward a typologicaltopological map of Europe.
} 
(Gagnon and Tully, 2001). Union states --and those polities with similar compounded structures-- can also be distinguished within the general nation-state category. The cases of Spain and the United Kingdom are a case in point concerning union-states. In modern times, their polities developed in a peculiar manner allowing significant degrees of autonomy of their constituent parts. The union structure entailed internal variations based upon pre-union arrangements and rights (Rokkan and Urwin, 1983; Moreno and McEwen, 2005).

Pluri-nationality may be more politically significant in countries which have a highly decentralized or federal structure. Where territorial units coincide with sub-state national, linguistic or cultural boundaries, their political significance is likely to be reinforced. Where boundaries of national communities do not match the boundaries of the sub-state units, additional tensions can be created. For example, the prevalent view of Canada promoted in Quebec has been of two nations: Quebec and 'English Canada'. By contrast, the other nine provinces neither represent a political unit, nor do they conceive of themselves as representing a distinctive national community (Simeon, 2004).

In Europe as a whole, mass politics and welfare systems served during the twentieth century to 'crystallize' the nation-state, freezing cleavage structures, both functionally and territorially. Such processes reinforced the complex web of cultural systems, historical legacies, political arenas and institutional frameworks. But it also brought to the fore the uneasy establishment of structures of intergovernmental relations, always necessary in polities of a multilevel nature.

\section{Multiple identities and the legitimation of political institutions}

The revival of ethnoterritorial identities has coincided with an increasing challenge to the centralist model of the unitary state. Models of 'command-and-control' majoritarian democracy, as well as of Jacobin vertical diffusionism of power, seem to be in terminal retreat, a development taking place in parallel to supranationalization (Loughlin, 2012). In plural polities, decentralisation, federalisation and subsidiarity seek legitimacy by accommodating an institutional response to the stimuli of their internal diversity. They often comprise groups and countries with differences of identity, history, language or traditions. 
Multiple identities reflect the sedimentation of shared loyalties and political aspirations through the various levels of social adscription and political life. Sub-state identities, in particular, are often culturally or historically-constructed, and may survive alongside a sense of identification with and belonging to the nation-state or to larger continental frameworks. The markers of such identities are not set in stone. For social actors there is political capital in seeking to shape these identities. Where a people no longer identify with the political institutions governing them, the legitimacy of that system of government will be called into question. Nationalist parties, in particular, may thus engage in articulating identification with and belonging to the communities in whose name their claims for political autonomy are made.

How to interpret the changing nature of people's self-identification and sense of collective belonging is not an easy task for social scientists. In the last decades, sub-state and state levels of political life have been analyzed through the lenses provided by the concept of dual identity. This concerns the way in which citizens identify themselves in sub-state minority nations or regions within multinational democracies. It incorporates in variable proportions the ethnoterritorial (regional) identity and the state (national) identity. As a result of this compound ethnicity, citizens share their institutional loyalties at both levels of political legitimacy without any apparent fracture between them (Moreno, 2006).

Arguably, the quest for self-government and home-rule by regions and sub-state communities has proven to be in accordance with the variable manifestation of such duality in citizens' self-identification: the more regional ethnoterritorial identity prevails upon modern national state identity, the higher the demands for political autonomy. Complete absence of one of the two elements of dual identity would lead to a socio-political fracture and demands for selfgovernment would probably take the form of secessionist independence. Alternatively, forced assimilation would seek to impose homogeneity and acculturation. In other words, when citizens in a sub-state community identify themselves in an exclusive manner, the institutional outcome of such antagonism will also tend to be exclusive. The so-called 'Moreno Question' was set according to a scale of five categories, which provide data on levels of identity belonging, intensity and sharing in contexts of political duality. The central idea of the 'Moreno question' has been geared towards the selection by the respondents of one of the five main categories in the following scale, first applied in the case of Scotland in 1985: (1) I am Scottish, not British; (2) I am more Scottish than British; (3) I am 
equally Scottish and British; (4) I am more British than Scottish; and (5) I am British, not Scottish (Moreno, 1986).

Identity exclusiveness and demands for independence form a binary relationship in which any of the two elements may foster casual processes in a non-linear mode. Certainly the two of them can reinforce each other, but no interconnection can be set a priori. Accordingly, the political mobilization of people's identities is subject to contingent factors. Among these, sociotropic behaviour is of a paramount importance. Perception, after all, cannot be considered as stable and linear. Likewise, identity cannot be made synonymous to belonging. Behind this equation there is a long-standing academic discussion about primordialism (and even biological determinism) and social constructivism.

In the illustrative case of Catalonia and Spain, the effects of the economic crisis unleashed in 2007-08 may have contributed to the political mobilization of Catalan ethnoterritorial identity. This occurrence was further exacerbated by a centre-periphery conflict between regional and central governments. Along this line of argument, the intensification of Catalan self-identification was also part and parcel of the economic quest put forward for the cause of independence. The secessionist 'window of opportunity' provided by the so-called Great Recession was maximized by sub-state nationalist discourses geared to the achievement of future scenarios of prosperity (Serrano, 2013). This economic 'rationalization' of the goal of separation of Catalonia from the rest of Spain could have greatly influenced the mobilization of Catalan forms of self-identification -primarily of those individuals expressing identities of 'Only Catalan' and 'More Catalan than Spanish' (Muñoz and Tormos, 2015). ${ }^{6}$ However the argument about which factor comes first and is more prevalent --identity o autonomy demands-- is rather circular (McCrone and Bechhofer, 2015). Identity can also have a much greater impact for political mobilization than a positive evaluation of the economic consequences of independence over the status quo (Sinnott, 2006; Burg, 2015).

If identification with the political community could facilitate the perception of a 'common good' and improve the performance of any

\footnotetext{
${ }^{6}$ These authors pointed out that preferences for independence were strongly associated with the judgment that living standards in Catalonia would improve after independence. However, regression analyses underscore the overwhelming effect of identity on preference for independence over the status quo. They made it clear that, on the likelihood of preferring independence over the status quo, identities have much greater positive effects than either preference for control of tax revenues or the likelihood of economic gains from independence.
} 
given political system, the perception of a good performance of the political system could also foster collective pride and strengthen such identification (Martínez-Herrera, 2010). Strategies for managing diversity in multilevel polities can provide resources for institutional legitimation. Likewise, they may emphasize integration and inclusion of ethno-cultural differences by promoting the constitutional autonomy and empowerment of those groups or territories involved (Choudhry, 2008). A main concern put forward by the advocates of the politics of recognition within multinational polities, is precisely that the promotion of collective rights in multicultural societies can be fully compatible with political liberalism (Taylor, 1994; Banting and Kymlicka, 2006).

However, empirical studies on the interrelation of diversity within states, the production of public goods and the preservation of social cohesion have been inconclusive. Approximately half of those studies confirm (o refute) the hypothesis that the politics of recognition and diversity have a negative impact on social cohesion (Schaeffer, 2013). In the same vein, the determinant most affecting the legitimacy of social solidarity and the redistribution of public spending --including those societies with a higher degree of internal heterogeneity-- is the capacity and quality of government institutions as generators of social trust (Rothstein, 2015). In general terms, policies seeking to maintain some common bonds and unity are aimed to avoid the idea that too much emphasis on diversity may neglect the common bonds that unite communities and individuals. Different schemes are more likely to work more effectively in some contexts than in others. The institutional designs to be applied may account for different degrees of stability, social justice, legitimacy, equity, recognition, social integration, and accountability in a general framework of growing interdependencies.

\section{Interdependence within multilevel polities}

Political communities are constituted by individuals ruled and represented by the structures of a political system, whether supranational, national or sub-national (sub-state) (Easton, 1965). They can be regarded as territories in which political life develops and where political issues are debated and, eventually, agreed upon. Despite their differences in institutional arrangements and policy preferences for autonomy, political communities at sub-state level can embrace interdependencies as an enhancement of common aspirations and, arguably, as an alternative to preserve non secessionist self-government. 
In general, regionalism and nationalism aim at the promotion of their territorial interests, including demands for autonomy and independence (Henderson, Jeffery and Wincott, 2013). Both speak to political power, and they involve mechanisms of differentiation, which can involve various types of references (for example, language, culture, religion, or ancestry). The politicization of the ethnic identity is the conditio sine qua non for the spread of nationalism, an ideology which compels congruence between rulers and ruled sharing a same collective identity and ethnic membership (Gellner, 1983).

As a powerful modern ideology, two main types of nationalism can be distinguished. Firstly, a majority or state nationalism forged by modernization and industrialisation in the processes of state formation and nation-building. This form of nationalism has aimed at integrating either ethnically homogeneous societies, such as Germany or Sweden, or heterogeneous ones, such as Italy or the USA. Secondly, a minority or stateless nationalism --also labelled as peripheral--, which has been steered by powerful sub-state nationalist parties and policy entrepreneurs striving for political power by means of political mobilization for home rule.

Together with modernisation, organisational pluralism has characterised contemporary democracies. Robert Dahl (1971) has drawn the attention to the existence of different societal interests and has theorised on the various interpretations on what the common good is. Within the 'pluralistic game', Dahl pointed to how in 'polyarchies' individual equality among citizens is often replaced by a concurrential parity among groups or organizations of individuals. However, the emphasis on territorial identities and polities showing a significant degree of internal diversity ought not to be placed merely on distinctiveness, but also on those relationships of democracy, interaction and congruence, and the viability of territorial accommodation with polities of a plural composition. For Juan Linz (1997), the articulation of democracy, nationalism and federalism is an option to be further explored, something which sovereignist majority and minority nationalisms often tend to block as they tend to polarise their political aspirations in a conflictive manner. In this way, territorial complementarities and dichotomies tend to give way to confronting oppositions (Moreno and Lecours, 2010).

The issue of intergovernmental relations within the state has been usually analysed from the managerial perspective of administrative de-concentration and public choice criteria of efficiency. As concerned multilevel polities, the quest for multilevel governance is generally associated with the idea that it provides a deepening of democracy by means of more effective access of civil society to political decision- 
making. As a matter of fact, intergovernmental relations often hide the democratic element of accountability, as public officials in the design, elaboration and delivery of policies are not always directly responsible of their actions to the electorates in the territories where they operate. Local government, for instance, at times portraits a merely democratic façade of discretion in policy-making as their decisions are wholly pre-determined by central state requirements (Colino and del Pino, 2015).

Intergovernmental relations based on democratically elected representatives of central, meso, and local layers of government can also be regarded as a limit to the proliferation of quangos. These 'quasi-non-governmental-organizations' are generally created and appointed by central government and authorities. They can also refer to 'private-sector' bodies carrying out functions for government. ${ }^{7}$ Other non-elected public bodies, or the concentration of power on an elitist class of public officials, ${ }^{8}$ have made the operationalization of the principle of democratic accountability very difficult. Not surprisingly, bureaucratic and political practices based solely on meritocratic excellence and hierarchy are increasingly seen as being responsible for the encroachment of the so-called 'democratic deficit' in European political life.

All things considered, the strengthening of sub- and supra-state identities translate in new demands for accommodating multilevel governance in a changing world where globalization, and the extension of market values, has translated in the further loss of power and influence by the nation-state (Strange, 1996). Both processes of supra-nationalization integration --such as Europeanisation-- and decentralization of powers imply that policies are to be shaped by considerations beyond the national interests of the single states (Hooghe and Marks, 2001; Enderlein, Wälti and Zürn, 2010).

It has been argued that an era of national centralization has been followed by a period of decentralization in the advanced capitalist

\footnotetext{
7 In 1984, the Thatcher Government calculated that there were 1,680 such bodies in the UK and aimed --with no apparent success-- at introducing a minimal public control of their finances and management.

8 The enarches, or graduates of the prestigious National School of Administration (École National d'Administration) and similar institutions, have provided France with administrative and political leadership. Their code of conduct has traditionally been based on a high level of excellence of the public service, although decision-making has often been taken 'behind closed doors'.
} 
democracies. ${ }^{9}$ The processes of redistribution of power in a multitiered world of politics concern the renewed partnerships of governance. New suitable conceptual and methodological approaches are needed to grasp the spatial re-configurations of politics. However, one of the main difficulties that social scientists have yet to deal with is the 'methodological nationalism' bias towards prioritizing data and analyses having the nation state as the sole source for data collection. On dealing with multi-level govern (ment/ance), and as illustrated in the European context, there are statistical problems which impede comparison and commensurability. Some data --such as regional economic accounts-- are already available on Eurostat, but meso-level regions exist at different NUTS ${ }^{10}$ levels. This is a major obstacle to carry out research on the interdependencies of the new stakeholders and territorial partners involved (Jeffery and Wincott, 2010).

The unfolding of interdependent governance at the supranational European level is taking place through multilevel interactions. These interactions have mainly affected actors, regulatory powers and policy networks whose operations were traditionally confined to the national state arenas. Political interdependence within the EU is not an incentive for internal boundary-building and the establishment of self-centred compartments of governance. The ongoing Europeanization reaches out to citizens on the Old Continent as a whole, and much of EU legislation has an impact on people's daily life. 'Direct effect' is the principle that EU law may, if appropriately framed, confer rights on individuals which the courts of EU member states are bound to recognise and enforce.

As a result of its institutionalization, the European Union has emerged as a compound of policy processes conditioning in no small measure the formal sovereignty of the member states (MacCormick, 1999; Piattoni, 2010). However, the state formation of the 'United States of Europe' cannot be envisaged as the necessary end-result of Europeanisation (Moreno, 2003). The neo-functionalist school of thought has generally adopted the view that universal progress requires integration, which is made equal to cultural assimilation and to overreaching identity formation, along the lines of the American

\footnotetext{
${ }^{9}$ A study of 42 democratic or semi-democratic countries has found that, in the period 1950-2006, institutional reforms had taken place in the direction of greater regional authority by a ratio of 8 to 1 (Marks, Hooghe and Schakel, 2008).

10 NUTS acronym corresponds to 'Nomenclature of Territorial Units for Statistics', a hierarchical system for dividing up the economic territory of the EU. The NUTS classification lists 98 regions at NUTS 1 level (major socio-economic regions), 276 regions at NUTS 2 (basic regions for the application of regional policies), and 1342 regions at NUTS 3 (small regions for specific diagnoses).
} 
'melting-pot', or the multicultural 'salad bowl'. Alternatively, the establishment of common European rules may be regarded as the result of accommodating the long-standing history and cultural diversity within the mosaic of peoples in the Old Continent. The rescaling of governance can be regarded as an institutional response to the political demand of making territory and power congruent and to legitimate efficiency and policy-making according to citizens' multiple territorial identities.

\section{Governance re-scaling}

In general terms, and concerning 'bottom-up' processes of transnationalization, national governments have seen considerably diminished its role as a sovereign actor in policy-making and monopoliser of power resources. While reports of the death of the nation-state (Ohmae, 1995) have been greatly exaggerated, it has faced a loss of its predominance and scope from three distinctive sources. It has been confronted from above by the forces of continental integration and globalization. It has also been challenged from below by the reassertion of territorial minorities demanding increased political autonomy and threatening state secession. Finally, it has been functionally challenged by the advance of the market and individualized social relations, and by a declining confidence in and engagement with the formal political process (Keating, 2001).

Requests for governance re-scaling seek to accommodate an institutional response to social diversity, in both functional and territorial dimensions. As concerns the latter, the modern state has generally comprised --more often than not-- spatial communities and groups with differences of language, history or traditions. ${ }^{11}$ Withinstate variations have often been reflected in party systems, channels of elite representation or interest group articulation (Detterbeck, 2012).

While bottom-up claims for autonomy in policy-making have put forward the request of re-allocating governmental responsibilities, social partnerships between private, public and altruistic sectors have also aimed at improving arrangements for policy provision in a transversal fashion. Both vertical and horizontal dimensions are

11 When Walker Connor (1994) analyzed the composition of the 132 states which made up the United Nations in 1971, he concluded that only 12 of these were nation-states in which the political unit coincided with the national community. By 1984, he could describe only seven states as nation-states in the strict sense of the term. These included Denmark, Iceland, Japan, Luxembourg, the Netherlands and Portugal. 
closely related with territorial subsidiarity and democratic accountability in multinational polities. Let us briefly review these two guiding tenets as concerns Europeanisation.

In the EU, subsidiarization provides for decisions to be taken supranationally only if local, regional or national levels cannot perform better. In other words, the preferred locus for decision-making is as decentralized and closer to the citizen as possible. ${ }^{12}$ Political elites of the member states, reluctant to further the process of transnationalization, have stubbornly interpreted the subsidiarity principle as a safeguard for the preservation of their power to intervene centrally within their state arenas. They have insisted in placing the bottom-line of subsidiarity at the level of the memberstate, no further below. ${ }^{13}$

Subsidiarity and the 'unbundling of territoriality' are already having a direct impact on EU citizens' living conditions, following the notion that policy decision-making ought to be located at the level closest to the citizen. The purpose of subsidiarity is seen to limit the power of central authorities. 'Proximity' and 'proportionality' promote a protective measure against over-expansion of European control in matters resting upon the jurisdiction and prerogatives of each layer of government in a multi-tiered Europe. It also encourages co-ordination to manage growing interdependencies very much as happens with functional subsidiarity. The latter is increasingly articulated at the meso level of government by societal stakeholders and civil society actors, who often come together to exert influence upon policymaking (Kazepov, 2010: Keating, 2013).

Subsidiarity go hand in hand with the second guiding principle of Europeanisation: democratic accountability, which applies to the legitimacy of multi-governance institutions in the Old Continent based on the rule of law. Political discussion, negotiation and eventual agreement are thus necessary and sufficient conditions for

\footnotetext{
${ }^{12}$ As a matter of fact, the principle of subsidiarity enshrined in the Treaty of European Union of 1992 (Maastricht Treaty) contains two diverse definitions on subsidiarity. The first one is of a substantial nature and is included in the Preamble and Art. 1 and expresses a broad political and conceptual understanding concerning both criteria of proximity and proportionality. The second definition put forward in Art. 5 (originally $3 \mathrm{~b}$ ) is of a procedural character and its legal implementation has been rather problematic (van Hecke, 2003).

${ }^{13}$ Debates in the EU on the so-called 'subsidiarity watchdog' are illustrative of the difficulties in conciliating national and regional interests. Both layers of governments (national and regional) have been engaged in a dispute as whether an additional referral procedure before the entry into force of a European legislative measure --which would conflict with the powers vested on each tier of government- was to be introduced.
} 
democratizing political decision-making. Multilevel Europeans expect that decisions ought not to be taken behind-closed-doors, as often happens in opaque state-centred polities (Scharpf, 2003; Schmidt, 2006).

Normative views challenging governance re-scaling, in general, and policy subsidiarization, in particular, refer to the possible aggravation of inequalities and territorial disparities. This has often been the case in those nation states where regional policies deployed by central governments and elites have precisely 'frozen' --if not augmented-previous existing differences (for example, Italy's Mezzogiorno). This mode of articulation of regional interests --not accountable democratically to regional institutions-- has often impeded policy innovation and mobilization and has been responsible for the encroachment of inefficient central policy provision.

Subsidiarity has also been interpreted as providing a justification for re-centralization, when central authorities assert than the lower tiers of governance are not able to perform better, or when they feel there is need for a uniform discipline in a policy area at the general level. The political elements in assessing when a tier of government is better equipped for policy provision may become an intractable Gordian knot. It is certainly difficult to establish 'objectively' when a region or local political community is unable to self-management and self-regulation. In such situations, inputs by national and transnational actors and institutions could be crucial for the maintenance of minimum common standards of living conditions, although such interventions can also perpetuate vertical clientelism, 'race to the bottom' practices and, after all, political anomie. While some regions and sub-state administrations have implemented cuts in their policy provision in order to accomplish stabilization of public debt (particularly during the Great Recession after the 2007-08 crisis), other regions have followed political credit-claiming with policy expansion and universalization of citizenship entitlements. All things considered, to depoliticize territorial politics by promoting 'neutral' concepts of multilevel governance has its limits in the very nature of social diversity and conflict.

\section{Concluding remarks}

Individuals live in multilevel contexts and incorporate intersubjective understandings of their communities of belonging. These contexts exert an impact on attitudes to policy, to the political legitimacy of political institutions, and to their membership in political communities. Traditionally, the emotional force of nationhood, and 
the solidarity and mutual belonging it engenders, have served political purposes. Accordingly, the idea that the nation-state best represents a people sharing a common identity and a set of civic values has aimed at: (a) enhancing its legitimacy; (b) fostering citizens' participation in the political process; and (c) underpinning much of the discourse used to justify public policy-making and governmental action. Just as appeals to a sense of statehood have been made to provide moral justification for military action, a shared nation-state identity has also been drawn upon to justify state intervention in domestic spheres. For example, increases (or decreases) in redistributive taxation, or legislation concerning social or moral issues, may be justified in the name of the national community and the values it is deemed to espouse.

The picture seems to become more complex when citizens' manifest multiple identities and diverse territorial allegiances in a context of multi-polities and increasing continentalization. But there is no intrinsic contradiction in legitimizing multilevel governance. Thus, different packages of policy provision may respond to the demands of autonomy and solidarity in plural and transnational institutional settings. Social policy-making, for instance, is highly shaped by local cultures and life styles, and is less likely to be dealt with in a homogenous and centralized manner from a supra-national entity. Regions have come to re-assert their political identities by means of implementing policies for welfare development and advancing social citizenship, particularly in those areas of labour activation, social assistance, care services and the policy closure of safety nets of welfare protection (Kazepov 2008; Moreno, 2013).

Regarding the case of Europeanisation to which this chapter has paid a closer attention, political attitudes are significantly related to citizens' identification. Arguably, the peoples of Europe have internalized a distinctive set of political, economic and social norms and values that are gradually recasting national or state-centred perspectives. Processes of Europeanisation and the eventual establishment of a demos relate to the manner in which individuals' identities are nested within local, regional and state communities. This reality has major implications for governance re-scaling in multitiered Europe.

Developments concerning multilevel governance and re-centralization are taken place simultaneously. While some regions and sub-state administrations have implemented economic policies of retrenchment and cuts in their expenditure for accomplishing stabilization of central public debt, other regions have followed alternative policies of creditclaiming with policy expansion and universalization of citizenship 
entitlements (Andreotti et al, 2012; McEwen, 2014). In parallel, supranationalization and the maintenance of a distinctive European social model are challenged by alternative models of individual recommodification and emergent neo-slavery, practices instigated in other world areas (for example, Anglo North America and Asian emergent economies) (Moreno, 2013).

Identity exacerbation is increasingly subject to political demands put forward by nationalist and populist parties. These aim at achieving power by putting issues concerning territorial politics high in their political agendas. The ongoing situation is not clear-cut concerning future scenarios for the interplay between multiple territorial identities and multilevel polities. But it has unquestionably become a major embedding factor in contemporary political life.

\section{Bibliographical references}

Andreotti, Alberta; Mingione, Enzo and Polizzi, Emanuele (2012), 'Local welfare systems: A challenge for social cohesion', Urban Studies, 49 (9): 1925-40.

Banting, Keith and Kymlicka, Will (2006), Multiculturalism and the welfare state. Recognition and redistribution in contemporary democracies. Oxford: Oxford University Press.

Berg, Linda (2007), Multilevel Europeans. The Influence of Territorial Attachments on Political Trust and Welfare Attitudes, Gothenburg: Göteborgs universitet.

Burg, Steve L. (2015), 'Identity, Grievances, and Popular Mobilization for Independence in Catalonia', Nationalism and Ethnic Politics, 21 (3): 289-312.

Choudhry, Sujit (ed.) (2008), Constitutional Design for Divided Societies: Integration or Accommodation? New York: Oxford University Press.

Colino, César and Eloísa del Pino (2015), 'National and European patterns of public administration and governance', in José M. Magone (ed.), Routledge Handbook of European Politics, London: Routledge, pp. 611-39. 
Connor, Walker (1984), The National Question in Marxist-Leninist Theory and Strategy, Princeton, NJ: Princeton University Press.

Connor, Walker (1994), Ethnonationalism. The Quest for Understanding, Princeton, NJ: Princeton University Press.

Dahl, Robert A. (1971), Polyarchy, Participation and Opposition, New Haven, CT: Yale University Press.

Detterbeck, Klaus (2012), Multi-Level Party Politics in Western Europe. New York: Palgrave Macmillan.

Deutsch, Karl W. (1966), Nationalism and Social Communication (2nd edition), New York: MIT. Press.

Easton, David (1965), A Systems Analysis of Political Life, New York: Wiley.

Enderlein, Henrik, Sonja Wälti and Michael Zürn (eds.) (2010), Multilevel Governance Handbook. Cheltenham: Edward Elgar.

Faist, Thomas (2001) 'Social Citizenship in the European Union: Nested Membership', Journal of Common Market Studies, 39 (1): 37-58.

Flora, Peter, Stein Kuhnle and Derek Urwin (eds.) (1999), State Formation, Nation-Building, and Mass Politics in Europe. The Theory of Stein Rokkan, Oxford: Oxford University Press.

Gagnon, Alain-G. and James Tully eds.) (2001), Multinational Democracies, Cambridge: Cambridge University Press.

Gellner, Ernest (1983), Nations and Nationalism, Ithaca, NY: Cornell University Press.

Henderson, Ailsa, Charlie Jeffery and Daniel Wincott (eds.) (2013), Citizenship after the Nation State. Regionalism, Nationalism and Public Attitudes in Europe, Basingstoke: Palgrave Mcmillan.

Hepburn, Eve (2011), 'Between Region and State: Rescaling Citizenship in a Multilevel System', in Tassilo Herrschel and Pontus Tallberg (eds.), The Role of regions? Networks, Scale, Territory, Kristianstad: Region Skåne, pp. 57-72.

Hooghe, Liesbet and Gary Marks (2001), Multilevel Governance and European Integration, Lanham, MD: Rowman \& Littlefield. 
Jeffery, Charlie and Daniel Wincott (2010), 'The challenge of territorial politics: Beyond methodological nationalism', in Hay, C. (ed.), New Directions in Political Science, Basingstoke: Palgrave Macmillan, pp. 167-88.

Kazepov, Yuri (2008), 'The subsidiarization of social policies: Actors, processes and impacts', European Societies, 10 (2): 247-73.

Kazepov Yuri (ed.) (2010), Rescaling Social Policies: Towards Multilevel Governance in Europe, European Centre Vienna, Farnham: Ashgate.

Keating, Michael (2001), Plurinational Democracy: Stateless Nations in a Post-Sovereignty Era. Oxford: Oxford University Press.

Keating, Michael (2013), Rescaling the European State. The Making of Territory and the Rise of the Meso. Oxford: Oxford University Press.

Kymlicka, Will (1995), Multicultural Citizenship: A Liberal Theory of Minority Rights, Oxford: Clarendon Press.

Linz, Juan J. (1997), Democracy, multinationalism and federalism, Madrid: Instituto Juan March de Estudios e Investigaciones (CEACS).

Loughlin, John (2012), Nationalism, Ethnicity and the State: Making and Breaking Nations, London: Sage

MacCormick, Neil (1999), Questioning Sovereignty, Oxford: Oxford University Press.

Marks, Gary, Liesbet Hooghe and Arjan H. Schakel (2008), 'Patterns of Regional Authority', Regional and Federal Studies, 18: 167-81.

Marshall, Thomas H. (1950) Citizenship and Social Class and Other Essays. Cambridge: Cambridge University Press [in Thomas $\mathrm{H}$ Marshall and Tom Bottomore, 1992, Citizenship and social class. London: Pluto Press].

Martínez-Herrera, Enric (2010), 'Competing national identities and democratization: a theoretical and comparative analysis', in André Lecours and Luis Moreno (eds.) (2010), Nationalism and Democracy. Dichotomies, Complementarities, Oppositions, New York: Routledge, pp. 80-99. 
Moreno, Luis (1986), Decentralisation in Britain and Spain: The cases of Scotland and Catalonia, doctoral thesis, pp. 534. Edinburgh: National Library of Scotland.

Moreno, Luis (2001), The Federalization of Spain. London: Frank Cass/Routledge.

Moreno, Luis (2003), 'Europeanisation, Mesogovernments and Safety Nets', European Journal of Political Research, 42 (2): 185-199.

Moreno, Luis (2005), 'Multiple identities and global mesocommunities', in Guy Lachapelle and Stéphane Paquin (eds.), Mastering Globalization. New Sub-States' Governance and Strategies, New York: Routledge, pp. 127-140.

Moreno, Luis (2006), 'Scotland, Catalonia, Europeanisation and the Moreno question', Scottish Affairs, 54: 1-21.

Moreno, Luis (2013), 'Multilevel citizens, new social risks and regional welfare', in Andrzej Marcin Suszycki and Ireneusz Paweł Karolewski (eds.), Citizenship and identity in the welfare state. Baden-Baden: Nomos, pp. 67-85.

Moreno, Luis and César Colino (2010), 'Introduction: Diversity and Unity in Comparative Perspective', in Luis Moreno and César Colino (eds.), Diversity and Unity in Federal Systems, Montreal \& Kingston/London/Ithaca: McGill-Queen's University Press, pp. 3-15.

Moreno, Luis and André Lecours (2010), 'Introduction: tensions and paradoxes of a multifaceted relationship', in André Lecours and Luis Moreno (eds.), Nationalism and Democracy. Dichotomies, Complementarities, Oppositions, New York: Routledge, pp. 3-15.

Moreno, Luis and Nicola McEwen (2005), 'Exploring the territorial politics of welfare', in Nicola McEwen and Luis Moreno (eds), The Territorial Politics of Welfare, New York: Routledge, pp. 1-40.

McCrone, David and Bechhofer, Frank (2015), Understanding National Identity. Cambridge: Cambridge University Press.

McEwen, Nicola (2014), 'The Smith Commission Report: A focus on welfare - Devolution (Further Powers) Committee Meeting', Centre on Constitutional Change, accessed on 15 April 2017 at http://www.centreonconstitutionalchange.ac.uk/blog/smithcommission-report-focus-welfare-devolution-further-powerscommittee-meeting. 
Muñoz, Jordi and Raül Tormos (2015), 'Economic expectations and support for secession in Catalonia: between causality and rationalization', European Political Science Review, 7 (2): 315-41.

Ohmae, Kenichi (1995), The End of the Nation State: The Rise of Regional Economies, New York: The Free Press.

Piattoni, Simona (2010), The Theory of Multilevel Governance: Conceptual, Empirical, and Normative Challenges, New York: Oxford University Press.

Rokkan, Stein and Derek Urwin (1983), Economy, Territory, Identity. Politics of West European Peripheries, London: Sage.

Rothstein, Bo. 2015. 'Solidarity, Diversity and the Quality of Government.' Paper presented at the annual conference of the American Political Science Association, San Francisco, 11 September, 2015.

Safran, William (1987), 'Ethnic Mobilization, Modernization, and Ideology: Jacobinism, Marxism, Organicism and Functionalism', The Journal of Ethnic Studies, 15 (1): 1-31.

Schaeffer, Merlin. (2013), 'Ethnic diversity, public goods provision and social cohesion: Lessons from an inconclusive literature.' WZB Discussion Paper, No. SP VI 2013-103, accessed on 15 April 2017 at http://hdl.handle.net/10419/86148.

Scharpf, Fritz W. (2003), Problem-solving effectiveness and democratic accountability in the EU, MPIfG working paper, No. 03/1, accessed on 15 April 2017 at http://hdl.handle.net/10419/41664.

Schmidt, Vivien A. (2006), Democracy in Europe. The EU and National Polities, Oxford: Oxford University Press.

Serrano, Ivan (2013), "Just a Matter of Identity?: Support for Independence in Catalonia," Regional \& Federal Studies, 23 (5): 523545.

Simeon, Richard (2004), 'Canada: Federalism, Language, and Regional Conflict', in Ugo M. Amoretti and Nancy Bermeo (eds.) Federalism and Territorial Cleavages, Baltimore, MD: Johns Hopkins University Press, pp. 93-122. 
Sinnott, R. (2006) 'An evaluation of the measurement of national, subnational and supranational identity in cross-national surveys', International Journal of Public Opinion Research, 18 (2): 211-223.

Strange, Susan (1996), The Retreat of the State. The Diffusion of Power in the World Economy, Cambridge: Cambridge University Press.

Taylor, Charles (1994), Multiculturalism. Examining the Politics of Recognition. Princeton, NJ: Princeton University Press.

Van Hecke, Steven (2003) 'The principle of subsidiarity: ten years of application in the European Union', Regional and Federal Studies, 13: 55-80.

Weber, Max (1947), The Theory of Social and Economic Organization, Oxford: Oxford University Press. 